\title{
ANALISIS PENGARUH WORD OF MOUTH TERHADAP KEPUTUSAN NASABAH UNTUK MENABUNG DENGAN BRAND EQUITY SEBAGAI VARIABEL MEDIASI
}

\author{
Zakiah Intan Fenanda \\ Nihayatu Aslamatis Solekah \\ Fakultas Ekonomi UIN Maulana Malik Ibrahim Malang \\ Email: zakiahfenanda@gmail.com \\ nihayatuaslamatiss@yahoo.co.id
}

\begin{abstract}
The development and dynamic of marketing of banking services products help to grow the variables that facilitate the influence of word of mouth against the decision to save. One of it is the brand equity that is a set of assets that is associated with a brand that adds or reduces the value of the company in the views of customers. The purposes of the research are to determine the influence of word of mouth against the decision to save through Brand Equity on the customer of Syariah BRI Bank of Malang.

The research used quantitative approach with survey method. The population of the research were all customers of Savings at Syariah BRI Bank of Malang. Sampling technique used accidental sampling with the number of respondents as much as 100 respondents. The dependent variable in the research was Savings Decision (Y), and independent variable was Word of Mouth (X), with Brand Equity (M) as the mediation variable. Data analysis technique used Path Analysis.

The research results indicated that the dimensions of word of mouth are Talkers, Topics, Taking Part and Tracking that directly influence against brand equity, and one dimension of word of mouth of tools have no effect against brand equity. Brand Equity directly influences the decision to save, all dimensions of word of mouth directly influence the decision to save, and Brand Equity can mediate the indirect influence of word of mouth against the savings decision.
\end{abstract}

Keywords: Word of Mouth, Savings Decision, Brand Equity

\section{PENDAHULUAN}

Perbankan Syariah di Indonesia pada saat ini telah mengalami pertumbuhan yang signifikan terhitung sejak kehadirannya.Hal ini tentu tidak dapat terwujud dengan sendirinya.Penerimaan masyarakat terhadap hadirnya perbankan syariah di Indonesia juga memegang peran sangat penting bagi perkembangan perbankan syariah. Besarnya pangsa pasar perbankan syariah terhadap masyarakat Indonesia yang mayoritas muslim juga turut berpengaruh terhadap eksistensi perbankan syariah 
hingga saat ini. Data statistik oleh Badan Pusat Statistik pada sensus terakhir tentang sebaran agama di Indonesia tahun 2010 memperoleh hasil $87,18 \%$ dari 237.641.326 penduduk Indonesia adalah pemeluk Islam (Badan Pusat Statistik, 2010). Tentu saja hal ini merupakan pangsa pasar potensial bagi industri perbankan syariah di Indonesia.

Pada era globalisasi saat ini, kebutuhan dan permintaan masyarakat terhadap jasa layanan perbankan telah masuk ke dalam berbagai aspek kehidupan yang tidak lepas dari kegiatan perekonomian. Suatu sikap yang wajar ketika seorang nasabah menentukan atau memilih institusi maupun produk manakah yang dapat memberikan nilai positif bagi nasabah serta dapat memberikan kemudahan dan keuntungan yang diharapkan. Kegiatan pemasaran yang dilakukan perbankan syariah dalam usaha menarik minat nasabah tentunya tidak bisa terlepas dari berbagai macam strategi pemasaran yang memiliki karakteristik sesuai dengan jenis strategi yang dipilih. Media pemasaran yang paling umum dijumpai adalah dengan menggunakan berbagai macam tools seperti brosur, pamflet, iklan, komunikasi massa, dan lain sebagainya. Padahal ada media komunikasi lain yang sangat efektif yaitu komunikasi word of mouth. Shirsavar et al. (2012) menjelaskan yang dimaksud word of mouth marketing yaitu memberikan orang alasan untuk membicarakan mengenai produk dan membuat berlangsungnya pembicaraan itu lebih mudah. Dengan kata lain, word of mouth adalah tentang percakapan nyata orang kepada orang lain atau konsumen ke konsumen lain.

Terdapat dua manfaat dari komunikasi mulut ke mulut atau word of mouth yakni; bersifat lebih meyakinkan dan tidak memerlukan biaya yang mahal. word of mouth dapat dikategorikan sebagai suatu metode yang sangat efektif dalam meyakinkan calon konsumen karena calon konsumen cenderung lebih mempercayai orang-orang di sekitarnya yang telah terlebih dahulu menggunakan produk atau jasa tertentu dibandingkan dengan iklan ataupun sarana pemasaran lain yang digunakan oleh para produsen (Chung, 2012).

PT Bank BRI Syariah merupakan salah satu perusahaan perbankan syariah yang paling dikenal oleh masyarakat Indonesia. Hal ini dibuktikan dengan adanya penghargaan Top Brand Award In Recognition of Outstanding Achievement in Building the Top Brand kategori Tabungan Syariah yang didapatkan oleh BRI Syariah pada tahun 2017. Selain itu di tahun 2017 Bank BRI Syariah mendapatkan penghargaan tambahan dari Majalah Infobank dalam Infobank Digital Award yang menganugrahkan penghargaan kepada BRI Syariah sebagai peraih peringkat 1 kategori digital Brand Tabungan Bank Umum Syariah. Penghargaan ini merupakan penghargaan terhadap rating-rating brand tabungan Syariah yang terpopuler dan paling banyak digunakan. 
Penghargaan ini menjadi simbol baiknya reputasi BRI Syariah selama ini bagi masyarakat (http://www.brisyariah.co.id/). Dari beberapa penghargaan yang diraih oleh PT Bank BRI Syariah, diasumsikan word of mouth memiliki peran dalam mempengaruhinya. Untuk menjawab asumsi sementara tersebut, penelitian ini diawali dengan terlebih dahulu melakukan wawancara awal terkait word of mouth terhadap keputusan menabung yang dilakukan pada sepuluh pemilik rekening tabungan BRI Syariah Kantor Cabang Malang yang dilakukan pada tanggal 29 september hingga 1 Oktober 2017.

BRI Syariah Kantor cabang Malang dipilih dengan pertimbangan lokasi yang sangat strategis di pusat Kota Malang yang berdekatan dengan banyak tempat penting antara dekat dengan perkantoran, perumahan, perkampungan, serta institusi pendidikan. BRI Syariah Kantor Cabang Malang diasumsikan memiliki nasabah produk tabungan dengan berbagai latar belakang pekerjaan, umur, dan lain-lain yang beragam dilihat dari lokasinya. Wawancara awal ini berisi dua pertanyaan yang memiliki tujuan untuk mengetahui apakah word of mouth melatarbelakangi 10 responden tersebut untuk menabung, dan pertanyaan kedua memiliki tujuan untuk mengetahui sumber word of mouth apa yang melatarbelakangi mereka untuk menabung. Dari hasil wawancara awal ini diperoleh hasil yang menyatakan bahwa pada pertanyaan pertama, 8 dari 10 responden atau $80 \%$ responden menyatakan bahwa word of mouth turut melatarbelakangi mereka dalam menabung di BRI Syariah Kantor Cabang Malang. Sedangkan 20\% responden menyatakan word of mouth tidak melatarbelakangi mereka untuk menabung di BRI Syariah Kantor Cabang Malang. Sedangkan pada pertanyaan kedua, 80\% responden menyatakan bahwa sumber word of mouth yang mereka dapatkan adalah berasal dari rekomendasi orang lain terutama orang terdekat.

Perkembangan dan dinamika yang terjadi dalam dunia pemasaran, ternyata turut menumbuhkan faktor atau variabel yang menjembatani pengaruh word of mouth terhadap keputusan pembelian (Khalid et al., 2013). Salah satu diantara faktor atau variabel tersebut adalah variabel brand equity. Suatu merek yang baik adalah merek yang dapat memberikan nilai tersendiri bagi suatu produk dan dapat memiliki posisi tersendiri di hati konsumen. Kekuatan merek dalam menarik kepekaan konsumen sering disebut dengan brand equity. Aaker (1992) menjelaskan yang dimaksud dengan brand equity adalah serangkaian aset dan kewajiban yang terkait dengan sebuah merek, nama, dan simbol yang menambah atau nilai yang diberikan sebuah produk atau jasa kepada perusahaan dan atau pelanggan. ekuitas merek inti ditentukan 
oleh empat dimensi atau elemen utama yaitu kesadaran merek, asosiasi merek, persepsi kualitas, dan loyalitas merek.

Penelitian terdahulu oleh Murtiasih et al. (2013) menyatakan bahwa word of mouth berpengaruh positif signifikan terhadap brand equity. Penelitian ini juga menyatakan bahwa word of mouth positif dapat membentuk ekuitas merek yang kuat. Penelitian lain yang senada diteliti oleh Armellini (2011) yang memperoleh hasil Word of mouth berpengaruh langsung dan positif terhadap Brand Equity. Armellini (2011) juga menyatakan bahwa word of mouth positif dapat meningkatkan ekuitas merek dan mempengaruhi pola pikir konsumen terhadap merek. Dengan kata lain pesan-pesan positif mengenai merek yang tersampaikan pada saat terjadinya word of mouth dapat meningkatkan kekuatan merek. Kedua penelitian terdahulu diatas mengindikasikan bahwa word of mouth ternyata tidak hanya berpengaruh dalam membentuk perilaku konsumen hingga mempengaruhi keputusan pembelian produk namun juga dapat mempengaruhi brand equity itu sendiri. Senada dengan penelitian oleh Murtiasih et al. (2013) dan Armellini (2011), dalam hasil penelitian oleh Aditya (2017) memperoleh hasil word of mouth memiliki pengaruh positif dalam memperkuat brand equity serta brand equity terbukti mampu memediasi pengaruh word of mouth terhadap niat beli konsumen hingga memutuskan untuk membeli produk. Sementara itu penelitian terdahulu yang menguji pengaruh brand equity terhadap keputusan pembelian dijelaskan oleh Andai (2016) dan juga Kazemi et al. (2013) yang keduanya memperoleh hasil bahwa brand equity berpengaruh langsung terhadap keputusan pembelian produk jasa selain itu hubungan brand equity dan keputusan pembelian produk jasa adalah pengaruh satu arah yakni brand equity ke keputusan pembelian produk jasa dan tidak berlaku sebaliknya.

Hasil-hasil penelitian terdahulu diatas kontradiktif dengan penelitian oleh Ratna et al. (2017) yang menemukan bahwa ternyata tidak semua dimensi dari brand equity mempunyai pengaruh pada keputusan pembelian. Hasil penelitian lain oleh Rahman dan Abadi (2017) menemukan bahwa word of mouth merupakan faktor yang tidak berpengaruh terhadap keputusan pembelian. Penelitian ini juga menjelaskan bahwa penyebab tidak berpengaruhnya keputusan word of mouth terhadap keputusan pembelian adalah dikarenakan indikator yang digunakan untuk mengukur word of mouth hanya sebatas pada membicarakan, mempromosikan dan merekomendasikan produk. Adanya gap riset dan celah penelitian Rahman dan Abadi (2017) merupakan urgensi dilakukannya penelitian ini. 
Tujuan penelitian ini adalah untuk mengetahui pengaruh dimensi word of mouth terhadap keputusan menabung melalui ekuitas merek (brand equity) sebagai variabel mediasi.

\section{KAJIAN PUSTAKA}

\section{Pengertian Word of Mouth}

Sernovitz (2012) menjelaskan yang dimaksud word of mouth marketing adalah memberikan orang alasan untuk membicarakan mengenai produk dan membuat berlangsungnya pembicaraan itu lebih mudah. Dengan kata lain, word of mouth adalah tentang percakapan nyata orang kepada orang lain atau konsumen ke konsumen lain. Sernovitz (2012) menjelaskan bahwa Word of Mouth memiliki lima elemen penting yang disebut dengan The FiveTs, yaitu : 1) Talkers, yaitu siapa pembicara dalam hal ini. Pembicara adalah konsumen yang telah mengkonsumsi produk atau jasa tertentu. Terkadang oranglain cenderung memilih atau memutuskan mengkonsumsi suatu produk atau jasa tergantumg kepada konsumen lain yang telah berpengalaman menggunakan produk atau jasa tersebut. 2) Topics, Word of Mouth menciptakan suatu pesan atau hal-hal tertentu yang membuat oranglain membicarakan suatu produk tertentu. Dengan kata lain topics adalah informasi atau topik yang dibicarakan mengenai suatu produk. 3) Tools, setelah mengetahui pesan atau perihal tertentu yang membuat oranglain membicarakan produk atau jasa tersebut maka dibutuhkan suatu alat untuk membantu agar pesan tersebut dapat berjalan. Dengan kata lain tools dalam word of mouth mengarah pada perlengkapan yang diperlukan untuk mempermudah konsumen dalam melakukan proses word of mouth. 4) Taking Part, atau partisipasi perusahaan. Merupakan bentuk partisipasi perusahaan dalam terjadinya word of mouth. 5) Tracking, yaitu pengawasan dari perusahaan terhadap proses Word of Mouth yang terjadi sehingga perusahaan dapat mengantisipasi terjadinya Word of mouth yang negatif mengenai produk.

\section{Pengertian Brand Equity}

Ekuitas merek adalah seperangkat asosiasi dan perilaku yang dimiliki oleh pelanggan merek, anggota saluran distribusi, dan perusahaan yang memungkinkan suatu merek mendapatkan kekuatan, daya tahan, dan keunggulan yang membedakan dengan para pesaing. Menurut Aaker (1992) ekuitas merek ditentukan oleh empat asset atau elemen utama yaitu brand awareness, brand associations, perceived quality, brand loyalty. 


\section{Pengertian Keputusan Pembelian}

Keputusan pembelian adalah suatu proses penyelesaian masalah yang terdiri dari pengenalan kebutuhan dan keinginan, pencarian informasi, penilaian sumber-sumber seleksi terhadap alternatif pembelian, keputusan pembelian dan perilaku setelah pembelian. Kotler dan Keller (2009) menyatakan bahwa proses psikologis dasar memainkan peranan penting dalam memahami bagaimana konsumen benar-benar membuat keputusan pembelian mereka. Periset pemasaran telah mengembangkan model tingkat proses keputusan pembelian. Proses pengambilan keputusan pembelian suatu produk atau jasa digambarkan dalam bentuk proses kegiatan pembelian dengan tahapan sebagai berikut

\section{Gambar 1}

Model lima tahap proses pembelian konsumen

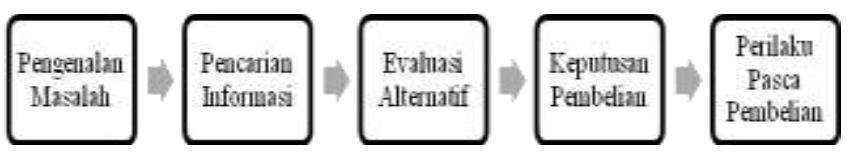

Sumber : Kotler \& Keller (2009)

\section{Kerangka Konseptual}

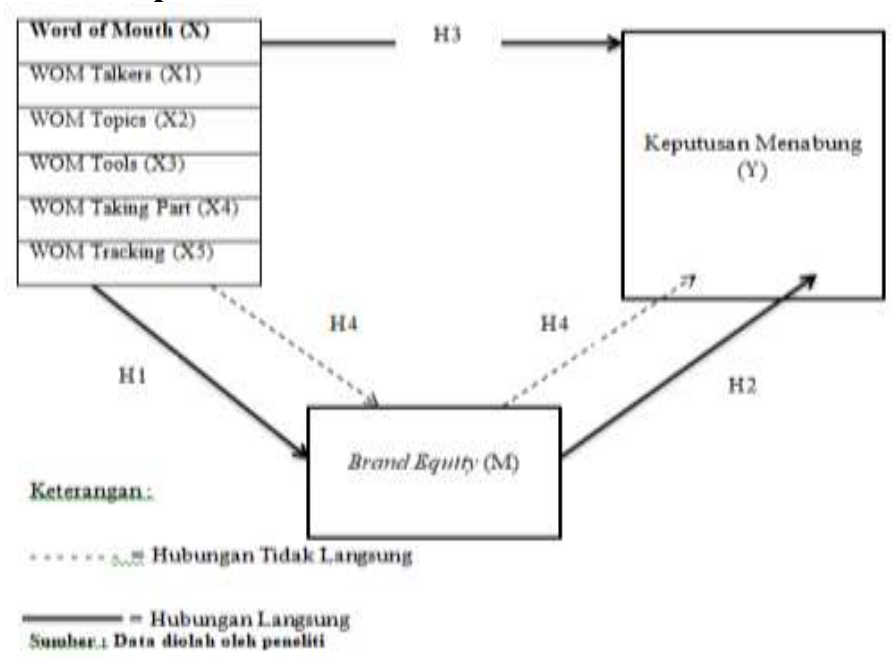

\section{METODE}

\section{Jenis Penelitian}

Penelitian ini menggunakan pendekatan kuantitatif Pelaksanaannya, proses penarikan sample menggunakan metode survey. Survey menurut Jogiyanto (2013) adalah metode pengumpulan data 
primer dengan memberikan pertanyaan-pertanyaan kepada respondenresponden secara tertulis. Adapun pengumpulan data pada penelitian ini adalah dengan menggunakan kuesioner yang merupakan salah satu instrument survey.

\section{Lokasi Penelitian}

Lokasi penelitian yang akan digunakan adalah Bank BRI Syariah Kantor Cabang Malang. BRI Syariah Kantor cabang Malang. Populasi dalam penelitian ini adalah seluruh pemilik rekening di Bank BRI Syariah Kota Malang. Penentuan jumlah sampel menggunakan rumus Rao (1996) sebagai berikut:

$$
n=\frac{Z^{2}}{4(m o e)^{2}}
$$

n : Jumlah Sampel

Z : Tingkat Keyakinan yang Dibutuhkan, 95\%

moe : margin of error atau kesalahan maksimum yang bisa ditoleransi

$$
\begin{aligned}
& n=\frac{(1,96)^{2}}{4(0,10)^{2}} \\
& n=96
\end{aligned}
$$

Ukuran sampel minimal yang digunakan dalam penelitian ini adalah sebanyak minimum 96 orang. Untuk memudahkan penelitian maka peneliti mengambil sampel sebesar 100 responden. Kriteria sampel pada penelitian ini adalah masyarakat yang telah memiliki rekening produk tabungan di Bank BRI Syariah Kantor Cabang Malang selama minimal 1 Tahun dan Berusia Minimal 17 Tahun. Serta teknik analisa data adalah dengan analisis jalur (Path).

\section{HASIL}

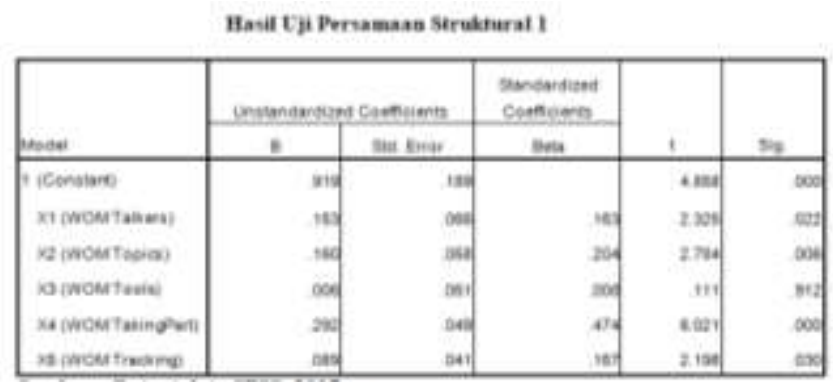




\section{H1.1 : Diduga terdapat pengaruh Word of Mouth Talkers terhadap Brand equity}

Nilai $t_{\text {hitung }}$ diperoleh pada tabel hasil uji persamaan struktural 1 diketahui bahwa besarnya $t_{\text {hitung }}$ variabel word of mouth talkers dan Brand equity (M) adalah sebesar 2,325. Artinya $t_{\text {hitung }}>t_{\text {tabel }}(2,325>$ 1,66 ). Dengan demikian Word of Mouth Talkers berpengaruh secara individu terhadap Brand equity. Dari tabel hasil uji persamaan struktural 1 , word of mouth talkers (X1) berpengaruh terhadap brand equity (M). Besar koefisien jalurnya adalah 0,163

\section{H1.2 :Diduga terdapat pengaruh Word of Mouth Topics terhadap Brand equity \\ Nilai $t_{\text {hitung }}$ diperoleh pada tabel hasil uji persamaan struktural 1} diketahui bahwa besarnya $t_{\text {hitung }}$ variabel word of mouth topics (X2) dan Brand equity (M) adalah sebesar 2,784. Artinya $t_{\text {hitung }}>t_{\text {tabel }}(2,784>$ 1,66 ). Dengan demikian word of mouth topics berpengaruh secara individu terhadap brand equity. Dari tabel hasil uji persamaan struktural 1, diketahui variabel word of mouth topics (X2) mempunyai Sig. sebesar 0,006 apabila dibandingkan dengan $\alpha=0,05(0,006<0,05)$ yang berarti bahwa word of mouth topics (X2) berpengaruh terhadap brand equity (M). Besar koefisien jalurnya adalah 0,204.

\section{H1.3 :Diduga terdapat pengaruh Word of Mouth Tools terhadap Brand equity}

Uji persamaan struktural 1 diketahui bahwa besarnya $t_{\text {hitung }}$ variabel word of mouth tools (X3) dan brand equity (M) adalah sebesar 0,111 . Artinya $t_{\text {hitung }}<t_{\text {tabel }}(0,111>1,66)$. word of mouth topics tidak berpengaruh secara individu terhadap brand equity. Dari tabel hasil uji persamaan struktural 1, diketahui variabel word of mouth tools (X3) mempunyai Sig. sebesar 0,912 apabila dibandingkan dengan $\alpha=0,05$ $(0,912>0,05)$ sehingga Ho diterima dan Ha ditolak yang berarti bahwa word of mouth tools (X3) tidak berpengaruh terhadap brand equity (M). Besar koefisien jalurnya adalah 0,008.

\section{H1.4 :Diduga terdapat pengaruh Word of Mouth Taking Part terhadap Brand equity}

Hasil uji persamaan struktural 1 diketahui bahwa besarnya $t_{\text {hitung }}$ variabel word of mouth taking part (X4) dan brand equity (M) adalah sebesar 2,784. Artinya $t_{\text {hitung }}>t_{\text {tabel }}(6,021>1,66)$. word of 
mouth taking part berpengaruh secara individu terhadap brand equity. variabel word of mouth taking part (X4) mempunyai Sig. sebesar 0,000 apabila dibandingkan dengan $\alpha=0,05(0,000<0,05)$ sehingga Ho ditolak dan Ha diterima yang berarti bahwa word of mouth taking part (X4) berpengaruh terhadap brand equity (M). Besar koefisien jalurnya adalah 0,474 .

\section{H1.5 :Diduga terdapat pengaruh Word of Mouth Tracking terhadap Brand equity}

Hasil uji persamaan struktural 1 diketahui bahwa besarnya $t_{\text {hitung }}$ variabel word of mouth tracking (X5) dan brand equity (M) adalah sebesar 2,198. Artinya $t_{\text {hitung }}>t_{\text {tabel }}(2,198>1,66)$. Dengan demikian hipotesis diterima yang memberikan kesimpulan bahwa word of mouth tracking berpengaruh secara individu terhadap Brand equity. Dari tabel hasil uji persamaan struktural 1, diketahui variabel word of mouth tracking (X5) mempunyai Sig. sebesar 0,030 apabila dibandingkan dengan $\alpha=0,05(0,030<0,05)$ sehingga word of mouth tracking (X5) berpengaruh terhadap brand equity (M). Besar koefisien jalurnya adalah 0,167 .

Hasil Uji pengaruh Brand equity terhadap Keputusan Menabung

\begin{tabular}{|c|c|c|c|c|c|}
\hline \multirow[b]{2}{*}{ Model } & \multicolumn{2}{|c|}{ Unstandardized Coefficient } & \multirow{2}{*}{$\begin{array}{c}\begin{array}{c}\text { Standardized } \\
\text { Coefficients }\end{array} \\
\text { Beta }\end{array}$} & \multirow[b]{2}{*}{$\mathrm{t}$} & \multirow[b]{2}{*}{ Sig. } \\
\hline & $B$ & Std. Error & & & \\
\hline M (Brand equity) & .314 & .092 & .257 & 3.408 & .00 \\
\hline
\end{tabular}

Sumber: Hasil output SPSS, 2017

\section{H2 Diduga terdapat pengaruh Brand equity (M) terhadap Keputusan Menabung ( $\mathrm{Y}$ )}

t_hitung variabel brand equity (M) dan Keputusan Menabung (Y) adalah sebesar 3,408. Artinya t_hitung $>$ t_tabel $(3,408>1,66)$. Dengan demikian hipotesis diterima yang memberikan kesimpulan bahwa Brand equity berpengaruh secara individu terhadap Keputusan Menabung. Variabel brand equity mempunyai Sig. sebesar 0,001 apabila dibandingkan dengan $\alpha=0,05(0,001<0,05)$ brand equity (M) berpengaruh terhadap Keputusan Menabung (Y). Besar koefisien jalurnya adalah 0,257. 


\begin{tabular}{|c|c|c|c|c|c|}
\hline & sil Uj & rsamaan & Struktural 2 & & \\
\hline Model & $\begin{array}{r}\text { Unsts } \\
\text { Coe }\end{array}$ & $\begin{array}{l}\text { dardized } \\
\text { cients }\end{array}$ & $\begin{array}{l}\text { Standardized } \\
\text { Coefficients }\end{array}$ & $\mathrm{t}$ & Sig. \\
\hline & $B$ & Std. Error & Bets & & \\
\hline 1 (Constant) &. .403 & .189 & & -2.132 & .036 \\
\hline $\begin{array}{l}\text { X1 (word of mouth } \\
\text { takers) }\end{array}$ & .189 & .060 & .165 & 3.134 & .002 \\
\hline $\begin{array}{l}\text { X2 (word of mouth } \\
\text { topics) }\end{array}$ & .195 & .054 & .203 & 3.631 & .000 \\
\hline $\begin{array}{l}X 3 \text { (word of mouth } \\
\text { toois) }\end{array}$ & .178 & .046 & .212 & 3.871 & .000 \\
\hline $\begin{array}{l}\text { X4 (word of mouth } \\
\text { takingpart) }\end{array}$ & .110 & .051 & .147 & 2.158 & .034 \\
\hline $\begin{array}{l}\text { X5 (word of mouth } \\
\text { tracking) }\end{array}$ & .099 & .037 & .152 & 2.651 & .009 \\
\hline
\end{tabular}

H3.1 Diduga terdapat pengaruh Word of Mouth Talkers (X1) terhadap keputusan menabung $(\mathrm{Y})$

$t_{\text {hitung }}$ variabel word of mouth talkers (X1) dan Keputusan Menabung (Y) adalah sebesar 3,134. Artinya $t_{\text {hitung }}>t_{\text {tabel }}(3,134>1,66$ ). word of mouth talkers berpengaruh secara individu terhadap Keputusan Menabung. Word of mouth talkers (X1) mempunyai Sig. sebesar 0,002 apabila dibandingkan dengan $\alpha=0,05(0,002<0,05)$ sehingga word of mouth talkers (X1) berpengaruh terhadap Keputusan Menabung (Y). Besar koefisien jalurnya adalah 0,165.

\section{H3.2 Diduga terdapat pengaruh Word of Mouth Topics (X2) terhadap keputusan menabung (Y)}

Nilai $t_{\text {tabel }}$ dilihat pada taraf signifikansi 0,05 di mana $\mathrm{df}=\mathrm{N}-5=$ 95. Oleh karena itu nilai $t_{\text {tabel }}$ pada $\mathrm{df}=95$ adalah 1,66 Nilai $t_{\text {hitung }}$ diperoleh pada tabel hasil uji persamaan struktural 2 diketahui bahwa besarnya $t_{\text {hitung }}$ variabel word of mouth topics (X2) dan Keputusan Menabung (Y) adalah sebesar 3,631. Artinya $t_{\text {hitung }}>t_{\text {tabel }}(3,631>$ 1,66). Dengan demikian hipotesis diterima yang memberikan kesimpulan bahwa word of mouth topics berpengaruh secara individu terhadap keputusan menabung.

Dari tabel hasil uji persamaan struktural 2, diketahui variabel word of mouth topics (X2) mempunyai Sig. sebesar 0,000 apabila dibandingkan dengan $\alpha=0,05(0,000<0,05)$ sehingga Ho ditolak dan Ha diterima yang berarti bahwa word of mouth topics (X2) berpengaruh terhadap keputusan menabung (Y). Besar koefisien jalurnya adalah 0,203 . 
H3.3 Diduga terdapat pengaruh Word of mouth Tools (X3) terhadap keputusan menabung (Y)

Nilai $t_{\text {tabel }}$ pada $\mathrm{df}=95$ adalah 1,66 Nilai $t_{\text {hitung }}$ diperoleh pada tabel hasil uji persamaan struktural 2 diketahui bahwa besarnya $t_{\text {hitung }}$ variabel word of mouth tools (X3) dan keputusan menabung (Y) adalah sebesar 3,871 . Artinya $t_{\text {hitung }}>t_{\text {tabel }}(3,871>1,66)$. Dengan demikian word of mouth tools berpengaruh secara individu terhadap Keputusan Menabung. Word of mouth tools (X3) mempunyai Sig. sebesar 0,000 apabila dibandingkan dengan $\alpha=0,05(0,000<0,05)$ word of mouth tools (X3) berpengaruh terhadap keputusan menabung (Y). Besar koefisien jalurnya adalah 0,212 .

\section{H3.4 Diduga terdapat pengaruh Word of mouth Taking Part (X4) terhadap keputusan menabung $(\mathrm{Y})$}

Pada tabel hasil uji persamaan struktural 2 diketahui bahwa besarnya $t_{\text {hitung }}$ variabel word of mouth taking part (X4) dan keputusan menabung (Y) adalah sebesar 2,158. Artinya $t_{\text {hitung }}>t_{\text {tabel }}(2,158>$ 1,66). word of mouth taking part berpengaruh secara individu terhadap Keputusan Menabung. Word of mouth taking part (X4) mempunyai Sig. sebesar 0,034 apabila dibandingkan dengan $\alpha=0,05(0,034<0,05)$ sehingga Ho ditolak dan Ha diterima yang berarti bahwa word of mouth taking part (X4) berpengaruh terhadap keputusan menabung (Y). Besar koefisien jalurnya adalah 0,147

\section{H3.5 Diduga terdapat pengaruh word of mouth tracking (X5) terhadap keputusan menabung $(\mathrm{Y})$}

Nilai $t_{\text {tabel }}$ dilihat pada taraf signifikansi 0,05 di mana $\mathrm{df}=\mathrm{N}-5=$ 95. Oleh karena itu nilai $t_{\text {tabel }}$ pada df $=95$ adalah 1,66 Nilai $t_{\text {hitung }}$ diperoleh pada tabel hasil uji persamaan struktural 2 diketahui bahwa besarnya $t_{\text {hitung }}$ variabel word of mouth tracking (X5) dan keputusan menabung (Y) adalah sebesar 2,651. Artinya $t_{\text {hitung }}>t_{\text {tabel }}(2,651>$ $1,66)$. Dengan demikian hipotesis diterima yang memberikan kesimpulan bahwa word of mouth tracking berpengaruh secara individu terhadap Keputusan Menabung.

Dari tabel hasil uji persamaan struktural 2, diketahui variabel word of mouth tracking (X5) mempunyai Sig. sebesar 0,009 apabila dibandingkan dengan $\alpha=0,05(0,009<0,05)$ sehingga Ho ditolak dan Ha diterima yang berarti bahwa word of mouth tracking (X5) berpengaruh terhadap keputusan menabung (Y). Besar koefisien jalurnya adalah 0,152 


\section{PEMBAHASAN}

Pengaruh Word Of Mouth Talkers, Word Of Mouth Topics, Word Of Mouth Tools, Word of Mouth Taking Part, dan Word of Mouth Tracking Terhadap Brand equity

Hasil pengujian pengaruh word of mouth talkers terhadap brand equity dengan analisis jalur (path) memperoleh hasil bahwa word of mouth talkers (X1) berpengaruh langsung terhadap brand equity (M). Artinya, pihak pemberi informasi (talkers) memiliki pengaruh signifikan dalam membentuk seperangkat asosiasi dan perilaku yang dimiliki oleh nasabah produk tabungan BRI Syariah. Oleh karena itu, kepercayaan penerima komunikasi word of mouth terhadap pemberi informasi harus baik. Hal ini mendukung penelitian terdahulu oleh Almossawi (2015) yang menyatakan bahwa efektifitas word of mouth tergantung dari seberapa besar kepercayaaan yang dimiliki oleh penerima pesan word of mouth punyai pada pemberi pesan. Semakin penerima pesan mempercayai pemberi pesan, semakin efektif proses word of mouth yang terjadi.

Hasil pengujuan word of mouth topics terhadap brand equity dengan analisis jalur (path) memperoleh hasil bahwa word of mouth topics (X2) berpengaruh langsung terhadap brand equity (M). Hal ini menunjukkan bahwa informasi atau topik yang dibicarakan orang lain terkait dengan produk tabungan BRI Syariah mempengaruhi persepsi dan loyalitas pelanggan terhadap BRI syariah melalui topik yang dibahas. Hal ini dapat dilihat dari mayoritas jawaban responden yang melalui proses komunikasi word of mouth dengan topik yang dibahas seputar fitur produk yang menarik, lokasi yang strategis dan juga pelayanan yang memuaskan, mayoritas responden mendengarnya dari orang lain. Oleh karena itu perusahaan harus menciptakan kesan yang baik mengenai produk tabungan BRI Syariah terkait dengan fitur, pelayanan dan juga lokasi sehingga informasi atau topik-topik yang dibicarakan oleh orangorang mengenai produk tabungan di BRI Syariah tersampaikan dengan baik untuk orang lain yang tentu saja berdampak baik bagi perusahaan untuk membangun ekuitas merek yang kuat.

Word of mouth tools (X3) terhadap brand equity (M) memperoleh hasil bahwa word of mouth tools (X3) tidak berpengaruh signifikan terhadap brand equity. Hal ini menunjukkan bahwa alat atau media serta perlengkapan yang diperlukan untuk mempermudah terjadinya penyampaian word of mouth ternyata tidak mempengaruhi persepsi nasabah terhadap produk tabungan BRI Syariah. Hal ini mengindikasikan bahwa proses komunikasi word of mouth pada nasabah BRI syariah lebih efektif dengan tidak adanya media perantara, dengan kata lain proses komunikasi word of mouth secara langsung lebih dapat mempengaruhi 
persepsi pelanggan serta seperangkat asosiasi yang dibayangkan pelanggan terhadap produk. Hal ini sesuai dengan penelitian terdahulu oleh Almossawi (2015) yang mengidentifikasikan 2 sumber dari word of mouth yang terdiri dari personal dan impersonal, hasil penelitian menunjukkan bahwa sumber personal lebih dapat mempengaruhi nasabah secara langsung dari sumber impersonal. Sumber personal yang terdiri dari orang-orang terdekat dan komunikasi langsung melalui tatap muka lebih mempengaruhi ekuitas merek pelanggan dibandingkan dengan sumber impersonal yang memakai perantara seperti artikel, koran, sosial media dan lain-lain. Hasil penelitian menunjukkan bahwa penelitian ini mendukung hasil temuan penelitian terdahulu.

Hasil pengujian word of mouth taking part (X4) terhadap brand equity (M) dengan analisis jalur (path) memperoleh hasil bahwa word of mouth taking part (X4) berpengaruh langsung terhadap brand equity (M). Hal ini menunjukkan bahwa partisipasi perusahaan dalam terjadinya word of mouth turut andil dalam mempengaruhi persepsi yang dibayangkan pelanggan terhadap produk tabungan BRI Syariah. Oleh karena itu perusahaan harus meningkatkan partisipasinya dalam penyebaran informasi melalui word of mouth. Pentingnya partisipasi perusahaan dalam menciptakan word of mouth yang positif telah dibuktikan dengan adanya penelitian terdahulu oleh Shirsavar et al. (2012) yang menyatakan bahwa salah satu faktor terpenting yang mempengaruhi secara langsung (direct effect) terhadap positive word of mouth adalah adanya hubungan baik antara perusahaan dengan nasabah. temuan ini mengindikasikan bahwa partisipasi perusahaan melalui adanya customer relationship dapat meningkatkan adanya positive word of mouth. Oleh karena itu bank harus menciptakan hubungan yang kuat dengan nasabah dan hal ini harus diikuti dengan komitmen bank untuk menjaga kepercayaan nasabah dan membangun ekuitas merek yang kuat.

Hasil pengujian pengaruh word of mouth tracking (X5) terhadap brand equity dengan analisis jalur (path) memperoleh hasil bahwa word of mouth tracking (X5) berpengaruh langsung terhadap Brand equity (M). Hal ini menunjukkan bahwa pengawasan dari perusahaan terhadap proses word of mouth yang terjadi sangat penting dilakukan karena berguna untuk mengantisipasi terjadinya word of mouth yang negatif. Bentuk pengawasan perusahaan dapat diwujudkan dalam bentuk penyediaan layanan konsumen yang mudah dihubungi agar nasabah dapat dengan mudah memberikan masukan kritik saran secara langsung terhadap perusahaan dan juga perusahaan perlu memantau serta merespon setiap kritik saran yang diberikan oleh nasabah. Hasil jawaban responden mendukung hal ini, ditunjukkan dengan jawaban mayoritas responden yang dominan ke arah sangat setuju (35\% untuk pernyataan 
pertama dan 30\% untuk pernyataan kedua) dan setuju (30\% untuk pernyataan pertama dan $31 \%$ untuk pernyataan kedua) adanya pengawasan perusahaan dalam proses komunikasi word of mouth.

Hasil penelitian yang mengemukakan bahwa word of mouth berpengaruh terhadap Brand equity senada dengan penelitian yang dilakukan oleh Severi et al. (2014). Severi juga menyatakan bahwa perusahaan dapat menciptakan dan meningkatkan ekuitas merek dari produk dan jasa untuk kemudian dengan mudah menarik konsumen dengan cara memaksimalkan word of mouth. Selain itu perusahaan perlu memastikan calon nasabah menerima word of mouth di tempat dan waktu yang tepat. Perusahaan perlu mengingat dan memprioritaskan word of mouth sebagai strategi utama mereka karena pada penelitian yang dilakukan oleh Severi et al. (2014) menunjukkan bahwa word of mouth memiliki pengaruh langsung dan tidak langsung dengan dimensidimensi brand equity.

\section{Pengaruh Brand equity terhadap Keputusan Menabung}

Hasil pengujian Brand equity terhadap keputusan menabung dengan analisis jalur (path) menunjukkan bahwa Brand equity atau ekuitas merek berpengaruh langsung terhadap keputusan menabung. Hal ini menunjukkan bahwa seluruh elemen ekuitas merek mempengaruhi keputusan menabung konsumen karena ekuitas merek yang kuat akan mengurangi keinginan konsumen untuk berpindah ke merek lain dan loyal terhadap produk tabungan BRI Syariah.

\section{Pengaruh Word of Mouth Talkers, Word Of Mouth Topics, Word Of Mouth Tools, Word Of Mouth Taking Part,Word Of Mouth Tracking terhadap Keputusan Menabung}

Hasil pengujian word of mouth talkers (X1) terhadap keputusan menabung dengan analisis jalur (path) memperoleh hasil bahwa word of mouth talkers (X1) memiliki pengaruh langsung terhadap keputusan nasabah untuk menabung dengan nilai beta sebesar 0,165 dan tingkat signifikansi sebesar 0,002. Hal ini menunjukkan bahwa seseorang yang memberikan informasi mengenai produk tabungan di BRI Syariah memiliki peran yang sangat penting dalam mempengaruhi keputusan untuk menabung. Adapun hasil penelitian terdahulu oleh Almossawi (2015) menyatakan bahwa efektivitas proses komunikasi word of mouth oleh talkers (senders) atau pemberi informasi tergantung dari dua faktor diantaranya trust (kepercayaan) dan experience (pengalaman). Dengan kata lain efektivitas word of mouth tergantung pada tingkat kepercayaan yang dimiliki oleh word of mouth receiver dalam hal ini penerima informasi kepada word of mouth senders (talkers) dalam hal ini pemberi informasi. Faktor lain yang mempengaruhi efektifitas word of mouth 
adalah seberapa berpengalaman talkers atau pemberi informasi pada produk yang direkomendasikan. Hal ini dapat terlihat pada item pernyataan pertama (X1.1) yang memiliki jawaban dominan setuju sebanyak 46\%. Hal ini menunjukkan bahwa sebagian besar responden mendengar dan mengetahui produk tabungan BRI Syariah melalui informasi dari orang terdekat yang telah terlebih dahulu berpengalaman untuk mencoba produk. Jawaban responden juga tidak jauh berbeda pada item pernyataan kedua (X1.2), ketiga (X1.3), keempat (X1.4), kelima (X1.5) dan keenam (X1.5) yang semuanya ditanggapi positif oleh responden.

Hasil pengujian word of mouth Topics (X2) terhadap keputusan menabung dengan analisis jalur (path) menujukkan bahwa word of mouth topics (X2) berpengaruh langsung terhadap keputusan menabung. Topik pada saat terjadinya komunikasi word of mouth juga menjadi dasar pengambilan keputusan nasabah untuk terus menggunakan produk tabungan BRI Syariah. Hal ini menunjukkan bahwa topik atau informasi yang dibahas pada saat terjadinya penyampaian informasi melalui word of mouth memegang peran penting yang menjadi perrtimbangan nasabah untuk menggunakan produk tabungan di BRI Syariah. Hal ini dapat terlihat pada jawaban responden pada item pernyataan pertama (X3.1) yang ditanggapi positif oleh mayoritas responden (43\% setuju dan $14 \%$ sangat setuju). Hal ini menunjukkan bahwa topik pembicaraan pada saat word of mouth yang membahas tentang pentingnya fitur produk yang menarik ditanggapi positif oleh mayoritas responden. Hal ini juga terjadi pada pengujian item pernyataan kedua (X3.2) dan ketiga (X3.3) yang menunjukkan bahwa topik word of mouth yang berisi tentang baiknya pelayanan dan juga strategisnya lokasi ditanggapi positif oleh mayoritas responden.

Hasil pengujian word of mouth tools (X3) terhadap keputusan menabung dengan analisis jalur (path) menunjukkan bahwa word of mouth tools berpengaruh langsung terhadap keputusan menabung. Hal ini menunjukkan bahwa alat atau perlengkapan yang diperlukan untuk mempermudah penyampaian informasi turut mempengaruhi keputusan menabung nasabah secara langsung dengan nilai beta sebesar 0,212 dan tingkat signifikansi 0,000. Murray (1991) dalam Almossawi (2015) menyatakan bahwa pembeli produk jasa lebih nyaman dengan informasi yang didapatkan dari sumber personal (orang-orang terdekat) dan sumber personal memiliki dampak yang lebih baik pada produk jasa dibandingkan dengan pada produk barang.Hal ini dapat dibuktikan dengan jawaban responden pada item pertama (X3.1) tentang penyampaian informasi melalui media sosial yang mendapatkan hasil mayoritas responden menyatakan tidak setuju (30\%) dan sangat tidak 
setuju (15\%). Hasil lain pada item pernyataan kedua (X3.2) dan (X3.3) tentang penyampaian informasi dengan media perkumpulan dan menggunakan media promosi yang mendapatkan hasil mayoritas responden menjawab setuju dan sangat setuju. Hal ini mengindikasikan bahwa peran word of mouth tools secara langsung lebih mempengaruhi nasabah untuk menabung Maka dari itu perusahaan perlu menyediakan media atau perlengkapan yang dapat mempermudah nasabah dalam menyampaikan pesan informasi dan melakukan komunikasi word of mouth secara langsung.

Hasil pengujian word of mouth taking part (X4) terhadap keputusan menabung dengan analisis jalur (path) menunjukkan bahwa word of mouth taking part berpengaruh langsung terhadap keputusan menabung. Hal ini menunjukkan bahwa tingkat partisipasi pihak BRI Syariah dalam penyebaran informasi melalui word of mouth berpengaruh langsung terhadap keputusan nasabah untuk menabung. Oleh karena itu perusahaan perlu meningkatkan partisipasinya dalam penyampaian informasi produk maupun layanan yang diberikan. Pendapat ini berdasarkan pada jawaban responden pada item pernyataan pertama (X4.1) tentang adanya pihak BRI Syariah atau informan lain yang berhubungan dengan BRI Syariah yang ikut berpartisipasi dalam proses word of mouth. Pada pernyataan ini sebesar $35 \%$ responden $(24 \%$ tidak setuju dan $11 \%$ sangat tidak setuju) tidak melihat adanya pihak BRI Syariah ketika terjadinya komunikasi word of mouth. Hal ini berhubungan dengan item pernyataan kedua (X4.2) tentang adanya pihak BRI Syariah akan menambah keyakinan responden atas informasi word of mouth yang disampaikan dan mempengaruhi keputusan menabung. Pada item pernyataan tersebut mayoritas responden $(29 \%$ setuju dan $18 \%$ sangat setuju) menginginkan adanya pihak BRI Syariah yang terlibat ketika terjadinya proses komunikasi word of mouth.

Hasil pengujian word of mouth tracking (X5) terhadap keputusan menabung dengan analisis jalur (path) menunjukkan word of mouth berpengaruh langsung terhadap keputusan menabung. Hal ini menunjukkan bahwa pengawasan dari perusahaan terhadap proses word of mouth yang terjadi sangat penting untuk dilakukan. Menurut hasil rekapitulasi jawaban responden pada item pernyataan pertama (X5.1) tentang perlunya adanya layanan konsumen untuk komplain dan memberikan masukan, mayoritas responden (35\% sangat setuju dan $30 \%$ setuju) menyetujui hal ini. Item pernyataan kedua (X5.2) tentang perlunya pihak BRI Syariah untuk memantau serta merespon informasi pada layanan konsumen juga memperoleh hasil yang hampir serupa dengan adanya 31 orang responden menjawab setuju dan 30 orang responden menjawab sangat setuju. Hal ini berarti mayoritas responden 
menyetujui perlunya pihak BRI Syariah untuk memantau dan merespon layanan konsumen.

Hasil pengujian brand equity terhadap keputusan menabung dengan analisis jalur (path) menunjukkan bahwa brand equity atau ekuitas merek berpengaruh langsung terhadap keputusan menabung. Hal ini menunjukkan bahwa seluruh elemen ekuitas merek mempengaruhi keputusan menabung konsumen karena ekuitas merek yang kuat akan mengurangi keinginan konsumen untuk berpindah ke merek lain dan loyal terhadap produk tabungan BRI Syariah.

Pengaruh Word of Mouth Talkers, Word of mouth Topics, Word of Mouth Tools, Word of Mouth Taking Part, dan Word of Mouth Tracking terhadap Keputusan Menabung melalui Brand equity

Hasil Pengujian Hipotesis pengaruh word of mouth talkers, word of mouth topics, word of mouth tools, word of mouth taking part dan word of mouth tracking terhadap Keputusan Menabung melalui brand equity yang diuji dengan uji sobel menunjukkan bahwa brand equity memediasi variabel word of mouth talkers, word of mouth topics, word of mouth taking part dan word of mouth tracking terhadap Keputusan Menabung. Hasil penelitian ini sejalan dengan penelitian yang dilakukan oleh Ratna et al. (2017) bahwa word of mouth berpengaruh langsung dan signifikan terhadap brand equity dan brand equity memediasi pengaruh word of mouth terhadap keputusan pembelian. Hasil penelitian ini mengindikasikan bahwa kekuatan elemen-elemen Brand equity yang terdiri dari kesadaran merek, asosiasi merek, persepsi kualitas oleh nasabah terhadap merek, serta loyalitas nasabah terhadap produk tabungan BRI Syariah turut mempengaruhi dan menentukan efektifitas pengaruh dari word of mouth terhadap keputusan menabung konsumen.

Sedangkan hasil uji sobel pada word of mouth tools terhadap keputusan menabung melalui brand equity menunjukkan hasil berbeda yaitu brand equity tidak memediasi pengaruh word of mouth tools terhadap keputusan menabung.

\section{KESIMPULAN}

4 dari 5 dimensi word of mouth diantaranya talkers, topics, taking part dan tracking berpengaruh langsung terhadap brand equity sedangkan 1 dimensi yaitu tools tidak berpengaruh langsung terhadap brand equity. Hal ini mengindikasikan bahwa proses komunikasi word of mouth pada nasabah BRI syariah lebih efektif dengan tidak adanya media perantara, dengan kata lain proses komunikasi word of mouth secara langsung lebih dapat membentuk persepsi pelanggan serta asosiasi yang dibayangkan pelanggan terhadap produk. 
Brand Equity berpengaruh langsung terhadap keputusan nasabah untuk menabung di BRI Syariah. Hal ini menunjukkan bahwa ekuitas merek BRI Syariah di benak nasabah turut mempengaruhi keputusan nasabah untuk memilih dan menggunakan produk tabungan di BRI Syariah.

5 dimensi word of mouth yang terdiri dari talkers, topics, tools, taking part dan tracking berpengaruh langsung terhadap Keputusan Nasabah untuk menabung. Hal ini mencerminkan bahwa komunikasi word of mouth yang diterima oleh nasabah produk tabungan BRI Syariah menjadi pertimbangan nasabah untuk menggunakan produk tabungan BRI Syariah.

4 dimensi dari word of mouth yaitu talkers, topics, taking part dan tracking memiliki pengaruh tidak langsung terhadap keputusan nasabah untuk menabung melalui Brand Equity. Sedangkan 1 dimensi word of mouth yaitu word of mouth tools tidak dimediasi oleh brand equity. Adapun pengaruh word of mouth tools terhadap keputusan menabung adalah pengaruh langsung. Hal ini berarti alat atau tools yang diperlukan untuk mempermudah nasabah dalam menjembatani proses word of mouth lebih memiliki efek langsung kepada keputusan nasabah untuk menabung, sedangkan alat word of mouth tersebut tidak mempengaruhi kesadaran nasabah terhadap merek, asosiasi yang dibayangkan nasabah terhadap merek, persepsi nasabah terhadap kualitas merek, serta loyalitas nasabah terhadap merek.

\section{DAFTAR PUSTAKA}

Aaker, D. A. 1992. The Value of Brand Equity. Journal of Business Strategy. Vol. 13 Iss 4, 27-32.

Aditya, K. Y., \& Wardana, I. M. 2017. Peran Brand Equity Dalam Memediasi Pengaruh Word Of Mouth Terhadap Niat Beli. E-Jurnal Manajemen Unud, Vol. 6, No. 2, 2017 ISSN : 2302-8912, 830-856.

Almossawi, M. M. 2015. The Impact of Word of Mouth (WOM) on the Bank Selection Decision of The Youth : A Case of Bahrain. International Journal of Business and Management; Vol. 10, No. 4; 2015 ISSN 1833-3850, 123-135.

Andai, J. 2016. Influence Of Brand Equity On Consumer Purchase Choices Among Pay Tv Subscribers In Nairobi, Kenya. Nairobi: School Of Business University Of Nairobi.

Armelini, G. 2011. The Effect of Word of Mouth in Customer Equity and Brand Equity. Chinese Business Review ISSN 1537-1506, 205-216. 
Badan Pusat Statistik. 2010. Kewarganegaraan, Suku Bangsa, Agama, dan Bahasa Sehari-hari Penduduk Indonesia. In A. Naim, \& H. Syaputra, Hasil Sensus Penduduk 2010 (p. 10). Jakarta: Badan Pusat Statistik.

Chung, S. L. 2012. Consumer Decision : The Effect of Word of Mouth. Intenational Journal of Organizational Innovation, 188-196.

http://www.brisyariah.co.id/

Jogiyanto. 2013. Pedoman Survey Kuesioner : Mengembangkan Kuesioner, Mengatasi Bias dan Meningkatkan Respon. Yogyakarta: Penerbit BPFE.

Kazemi, A., Hosseini, S. Y., \& Moradi, M. 2013. An Analysis of Influential Factors of Brand Equity and Its Impact on Consumer Buying Decision-The Selected Branches of Mellat Bank in Bushehr City as Case Study. International Journal of Academic Research in Business and Social Sciences November 2013, Vol. 3, No. 11 ISSN: 2222-6990, 422-432.

Khalid, S., Ahmed, M. A., \& Ahmad, Z. 2013. Word-of-Mouth Communications: A Powerful contributor to Consumers Decisionmaking in Healthcare Market. International Journal of Business and Management Invention ISSN (Online): 2319 - 8028, ISSN (Print): 2319 - 801X, 55-64.

Kotler, P., \& Keller. 2009. Manajemen Pemasaran I. Jakarta : PT Index.

Murtiasih, S., Sucherly, \& Siringoringo, H. 2013. How Word of Mouth Influence Brand Equity for Automotive Products in Indonesia. Procedia - Social and Behavioral Sciences 81, 40-44.

Rachman, R., \& Abadi, T. W. 2017. Komunikasi Word Of Mouth Dan Keputusan Pembelian Batik Bangkalan. Jurnal ASPIKOM, 285-295.

Ratna, A. R., Suharyono, \& Srikandi, K. 2017. The Influence of Word of Mouth (WOM) on Brand Equity and The Impact to Purchasing Decision. DOI https://doi.org/10.18551/rjoas.2017-05.20, 148154.

Rao, P. 1996. Measuring Consumer Perceptions Through Factor Analysis. The Asian Manager (February-March).

Sarwono, J. 2007. Analisis Jalur untuk Riset Bisnis dengan SPSS. Yogyakarta: Penerbit Andi. 
Sernovitz,. Andy. 2012. Word Of Mouth Marketing How Smart Companies Get People Talking. America : Published by Greenleaf Book Group Press Austin.

Severi, E., Ling, K. C., \& Nasermoadeli, A. 2014. The Impacts of Electronic Word of Mouth on Brand Equity in the Context of Social Media. International Journal of Business and Management; Vol. 9, No. 8; 2014 ISSN 1833-3850 E-ISSN 1833-8119 Published by Canadian Center of Science and Education, 84-96.

Shirsavar, H. A., Gilaninia, S., \& Almani, A. M. 2012. A Study of Factors Influencing Positive Word of Mouth in the Iranian Banking Industry. Middle-East Journal of Scientific Research 11 (4): , 2012 ISSN 1990-9233 IDOSI Publications, 454-460. 